\title{
Laboratory testing in the evaluation of a monoclonal protein: A practical framework for interpretation
}

\author{
B L Houston, MD; E Rimmer, MD, MSc; R Zarychanski, MD, MSc; M Seftel, MB ChB, MPH \\ Section of Hematology and Medical Oncology, Department of Internal Medicine, Max Rady College of Medicine, Rady Faculty of Health Sciences, \\ University of Manitoba, Winnipeg; and Department of Medical Oncology and Hematology, CancerCare Manitoba, Winnipeg, Canada
}

Corresponding author: B L Houston (bhouston@cancercare.mb.ca)

\begin{abstract}
Monoclonal proteins are immunoglobulins secreted by identical but abnormal plasma cells that are clones of a parent cell. While routine screening in the absence of signs or symptoms of disease is not recommended, testing is indicated in the diagnostic work-up for multiple myeloma and other plasma cell disorders. When indicated, a serum protein electrophoresis with immunofixation and serum free light-chain assay should be performed to determine the type and quantity of monoclonal protein. Using a case-based approach, we highlight common misconceptions with monoclonal protein investigations, and suggest a practical framework for diagnostic interpretation.
\end{abstract}

S Afr Med J 2019;109(10):719-722. https://doi.org/10.7196/SAMJ.2019.v109i10.14314

\section{Case 1}

Patient 1 is a 67-year-old woman with unexplained normocytic anaemia on routine blood tests. Her white blood cell (WBC) count is $9 \times 10^{9} / \mathrm{L}$ (normal range $4.5-11 \times$ $10^{9} / \mathrm{L}$; normal WBC count differential), $\mathrm{Hb} 10 \mathrm{~g} / \mathrm{dL}$ (normal range $14-18 \mathrm{~g} / \mathrm{dL}$ ), mean corpuscular volume $90 \mathrm{fl}$ (normocytic) and platelet count $560 \times 10^{9} / \mathrm{L}$ (normal range $\left.150-450 \times 10^{9} / \mathrm{L}\right)$. Electrolytes, renal and liver function are within normal limits. C-reactive protein is elevated $(30 \mathrm{mg} / \mathrm{L}$; normal $<5 \mathrm{mg} / \mathrm{L}$ ), total protein $96 \mathrm{~g} / \mathrm{L}$ (normal range $60-80 \mathrm{~g} / \mathrm{L}$ ) and quantitative immunoglobulins demonstrate an IgG of $24 \mathrm{~g} / \mathrm{L}$ (normal range 6.9 - $16.2 \mathrm{~g} / \mathrm{L}$ ), with normal IgM and IgA levels.

\section{Case 2}

Patient 2 is a 78 -year-old man with back pain and an osteolytic vertebral lesion on skeletal survey. His WBC count is $11 \times 10^{9} / \mathrm{L}$, $\mathrm{Hb} 10 \mathrm{~g} / \mathrm{dL}$ and platelet count $278 \times 10^{9} / \mathrm{L}$. His renal function is normal (creatinine $70 \mu \mathrm{mol} / \mathrm{L}$; normal range $44-106 \mu \mathrm{mol} / \mathrm{L})$. Serum protein electrophoresis (SPEP) demonstrates a monoclonal protein of $10 \mathrm{~g} / \mathrm{L}$, which is identified on immunofixation as IgG kappa.

\section{Case 3}

Patient 3 is a 65 -year-old man with anaemia ( $\mathrm{Hb} 9 \mathrm{~g} / \mathrm{dL})$, hypercalcaemia $(3.2 \mathrm{mmol} / \mathrm{L}$; normal range $2.1-2.6 \mathrm{mmol} / \mathrm{L}$ ) renal impairment (creatinine $400 \mu \mathrm{mol} / \mathrm{L}$ ), and back pain, with lytic lesions on X-ray imaging of the lumbar spine. SPEP and immunofixation are negative.
Do these patients have evidence of a monoclonal protein? Is additional testing required?

\section{What is a monoclonal protein?}

Testing for monoclonal proteins is indicated in the work-up for multiple myeloma or other plasma cell disorders. Many synonyms of monoclonal proteins exist, including M-protein, M-spike, M-band, monoclonal immunoglobulin, monoclonal gammopathy and paraprotein. A monoclonal protein is a unique immunoglobulin secreted by identical but abnormal plasma cells that are clones of a parent cell. The categorisation of the monoclonal protein depends on its components: the protein can be an immunoglobulin with both a heavy chain (IgG, IgA, IgM) and light chain (kappa (к), lambda $(\lambda)$ ), or an isolated light chain (without its heavy-chain counterpart) referred to as a free light chain (FLC) (Fig. 1).

The critical first step in interpreting a monoclonal protein investigation involves confirmation of clonality. An elevated total protein level, or an increase in quantitative immunoglobulins (IgG, $\operatorname{IgA}, \operatorname{IgM})$, is not necessarily a clonal process. A polyclonal increase in serum immunoglobulins is common with liver disease, infection, inflammation and other reactive causes.

\section{How do I test for \\ the presence of a} monoclonal protein?

Serum protein electrophoresis

SPEP separates serum proteins based on their size and charge. There are two

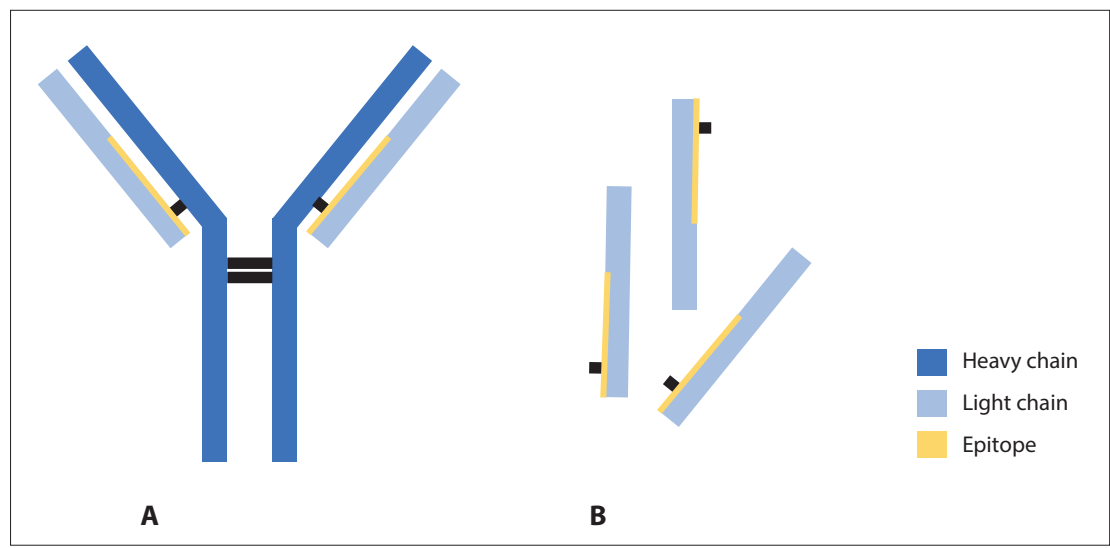

Fig. 1 (A). IgG antibody with both heavy and light chains. When the light chain is bound to the heavy chain the free light-chain (FLC) epitope is hidden and therefore unable to bind in the serum FLC immunoassay. (B) FLCs. When dissociated from its heavy chain counterpart, an epitope is exposed that allows binding in the serum FLC assay. 
major types of proteins in the blood: albumin and globulin. Globulins can be subdivided into alpha-1, alpha-2, beta-1, beta- 2 and gamma globulins, each with distinct electrophoretic properties. A homogenous spike in the gamma globulin region suggests a monoclonal gammopathy (Fig. 2). ${ }^{[1]}$ Importantly, SPEP quantifies the size of the monoclonal protein, but does not describe the type of protein (i.e. IgG kappa, IgA lambda). SPEP is insensitive to small monoclonal proteins and should therefore be accompanied by serum immunofixation. ${ }^{[2,3]}$

\section{Serum immunofixation}

Serum immunofixation is a complementary test to SPEP that is used to further characterise a suspected monoclonal protein. Antibodies directed against the different heavy- and light-chain subtypes result in distinct bands that allow identification of the clonal protein (Fig. 2). Immunofixation describes the type of monoclonal protein (e.g. IgG kappa) and has increased sensitivity $(\sim 10 \times)$ for detection of small monoclonal proteins not otherwise identified on protein electrophoresis. ${ }^{[4]}$

\section{Serum free light-chain assay}

While an SPEP is commonly regarded as the screening tool for multiple myeloma, $15-20 \%$ of patients with this condition will not be diagnosed when an SPEP is ordered in isolation. ${ }^{[5]}$ A serum FLC assay should be performed in addition to an SPEP and immunofixation, as the combination is highly sensitive to detect monoclonal light chains that would otherwise be missed by routine serum immunofixation techniques.

The serum FLC assay detects FLCs (e.g. Bence Jones proteins) using an automated immunoassay that reacts against epitopes normally hidden when bound to a heavy chain (Fig. 1). Interpretation of the serum FLC assay requires three parts: quantitative measurement of the kappa (normal range 3.3 - $19.4 \mathrm{mg} / \mathrm{L}$ ) and lambda (normal range 5.7 - $26.3 \mathrm{mg} / \mathrm{L}$ ) FLC levels, and calculation of the FLC ratio (kappa/lambda; normal range 0.26 - 1.65). In the presence of a plasma cell disorder, the clonal plasma cell population can disproportionately secrete either kappa or lambda FLCs, which will markedly alter the FLC ratio.

This ratio is critically important to the interpretation of FLC testing. States of polyclonal hypergammaglobulinaemia, such as infection and inflammation (increased production) and renal impairment (reduced renal clearance), can result in mild to modest elevations in FLCs. ${ }^{[6-8]}$ However, in these

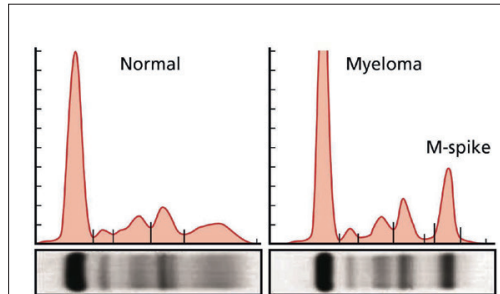

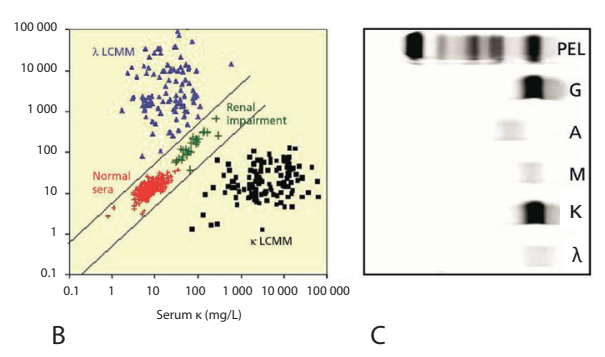

Fig. 2 (A). Serum protein electrophoresis. Left: a normal electrophoresis pattern. Right: an 'M-spike' in the gammaglobulin region, which suggests a monoclonal process. Clonality requires confirmation with immunofixation. (B) Serum free light-chain (FLC) assay. Normal distribution of kappa ( $\kappa$ ) and lambda ( $\lambda$ ) FLCs are represented in red. Increased FLCs in patients with renal impairment with a preserved FLC ratio are depicted in green. A disproportionate increase in lambda FLCs, suggestive of lambda lightchain multiple myeloma (LCMM), is represented in blue. An increase in kappa light chains, suggestive of kappa LCMM, is represented in black. (C) Serum immunofixation. The protein electrophoresis (PEL) pattern is included at the top of the image. The monoclonal protein is classified as an IgG kappa based on the bands highlighted with immunofixation. $(G=\operatorname{Ig} G ; A=\operatorname{IgA} ; M=\operatorname{IgM} ; \kappa=k a p p a ; \lambda=l a m b d a$.) Adapted with permission from the American Society of Hematology Self-Assessment Program. ${ }^{[1]}$

instances, the FLC ratio is only minimally impacted. In chronic kidney disease, a 'renal range' of FLC ratio elevation has been defined (range 0.37 - 3.1), although it is important to emphasise that ratio alterations beyond this require further investigation, regardless of kidney function. ${ }^{[9]}$

\section{Is urine protein electrophoresis testing ready for retirement?}

Historically, urine protein electrophoresis (UPEP) and immunofixation were used to increase the sensitivity of monoclonal protein detection. The requirement for a 24-hour urine collection and lack of sensitivity to low levels of abnormal FLCs generated enthusiasm to replace UPEP with the serum FLC assay. The combination of SPEP with immunofixation and serum FLC testing has sufficient sensitivity to negate the need for routine urine testing when screening for a monoclonal protein. ${ }^{[10,11]}$ The International Myeloma Working Group (IMWG) recommends that a serum FLC assay replace 24-hour urine immunofixation when screening for plasma cell disorders (with the notable exception of amyloid lightchain (AL) amyloidosis). ${ }^{[12,13]}$ While somewhat controversial, once a monoclonal protein is identified, one could consider using a 24 -hour UPEP with immunofixation to evaluate for potentially nephrotoxic concentrations of urinary light chains, although in the absence of renal impairment this is unlikely to change clinical management.

\section{What disorders} are associated with monoclonal proteins?

Monoclonal proteins are associated with a variety of plasma cell disorders, including monoclonal gammopathy of undetermined significance (MGUS), smoldering multiple myeloma, multiple myeloma and solitary plasmacytomas. Monoclonal proteins are also features of Waldenström macroglobulinaemia and systemic AL amyloidosis. The salient clinical features and test abnormalities of these disorders are included in Table 1 . The vast majority of monoclonal proteins ultimately result in a diagnosis of MGUS, a premalignant clonal condition that increases in frequency with age, affects $3 \%$ of the population $>50$ years of age, and is twice as common in patients of African ethnicity. ${ }^{[14,15]}$ MGUS is a precursor to conditions such as multiple myeloma, AL amyloidosis and Waldenström macroglobulinaemia, although the majority of patients with MGUS do not develop these conditions. Contemporary guidelines do not support routine screening for MGUS, as the diagnosis does not require specific therapy, has been associated with psychological harm to the patient, and is associated with significant healthcare costs. ${ }^{[16,17]}$ Therefore, it is imperative that the decision to pursue monoclonal testing be clinically justified (Table 1, Fig. 3).

\section{When should I test for a monoclonal protein?}

Monoclonal protein investigations (SPEP, immunofixation, and serum FLC assay) should be used to identify patients with plasma cell disorders (multiple myeloma being the most common). Indications to order SPEP screening are set out in Table 1 and Fig. 3. Routine screening with an SPEP (or serum FLC assay) is not indicated in the absence of signs or symptoms of an associated disorder. 
Table 1. Typical features of plasma cell disorders associated with a monoclonal gammopathy ${ }^{[18]}$

\begin{tabular}{|c|c|c|}
\hline Disorder & Symptoms & Test abnormalities \\
\hline Low-risk MGUS & None & $\begin{array}{l}\text { IgG M-protein }<15 \mathrm{~g} / \mathrm{L} \text { or IgM M-protein }<15 \mathrm{~g} / \mathrm{L} \text { with } \\
\text { normal CBC and examination; kappa or } \\
\text { lambda FLC }<100 \mathrm{mg} / \mathrm{L} ; \text { FLC ratio } 0.125-8.0\end{array}$ \\
\hline Other MGUS (not low risk) & None & $\begin{array}{l}\text { M-protein }<30 \mathrm{~g} / \mathrm{L} \text {, clonal bone marrow plasma cells }<10 \% \text {; } \\
\text { does not satisfy 'low risk' criteria above }\end{array}$ \\
\hline Smoldering multiple myeloma & None & $\begin{array}{l}\text { M-protein }>30 \mathrm{~g} / \mathrm{L} \text {, clonal bone marrow plasma cells }>10 \% \text {; } \\
\text { no biomarkers of malignancy }{ }^{*}\end{array}$ \\
\hline Multiple myeloma & $\begin{array}{l}\text { CRAB (hyperCalcaemia, Renal impairment, } \\
\text { Anaemia, and Bone lesions (related to } \\
\text { monoclonal protein) }\end{array}$ & $\begin{array}{l}\text { Clonal bone marrow plasma cells }>10 \% \text { or biomarker of } \\
\text { malignancy }\end{array}$ \\
\hline Solitary plasmacytoma & $\begin{array}{l}\text { Dependent on location of soft tissue or bone } \\
\text { lesion }\end{array}$ & $\begin{array}{l}\text { Biopsy-proven lesion with evidence of clonal plasma cells; } \\
\text { no evidence of multiple myeloma otherwise }\end{array}$ \\
\hline Systemic AL amyloidosis & $\begin{array}{l}\text { Can involve multiple organs such as kidney, } \\
\text { liver, heart, gastrointestinal tract and } \\
\text { peripheral nerves }\end{array}$ & $\begin{array}{l}\text { Positive amyloid staining by Congo red (any tissue); } \\
\text { mass spectrometry to confirm amyloid is light-chain related; } \\
\text { evidence of monoclonal plasma cell disorder }\end{array}$ \\
\hline
\end{tabular}

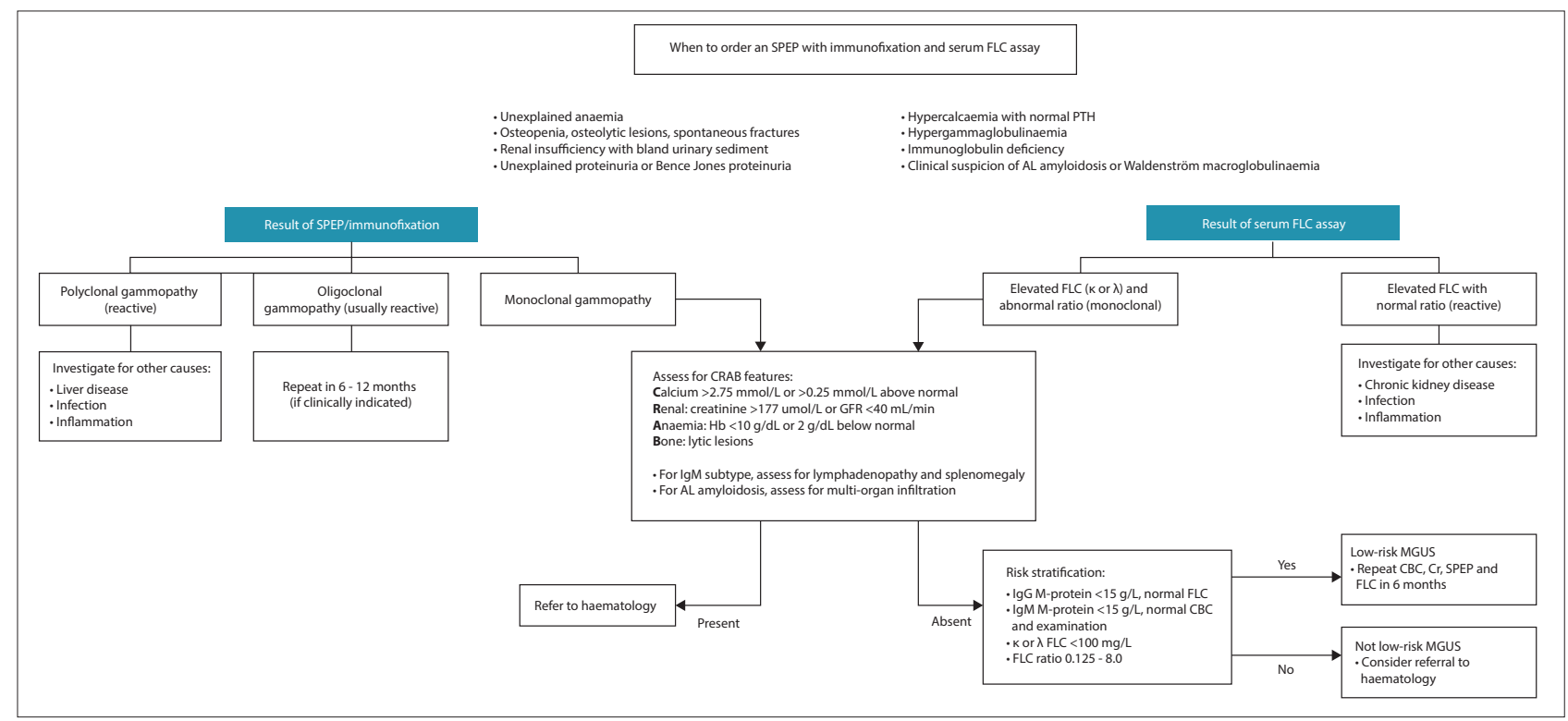

Fig. 3. Interpretation of serum protein electrophoresis and serum free light-chain assay results. (SPEP = serum protein electrophoresis; FLC = free light chain; $P T H=$ parathyroid hormone; $A L$ amyloidosis = amyloid light-chain amyloidosis; $\kappa=k a p p a ; \lambda=$ lambda; GFR = glomerular filtration rate; $H b=$ haemoglobin $; C B C=$ complete blood count MGUS = monoclonal gammopathy of undetermined significance; $C r=$ creatinine. $)$

When a monoclonal protein is identified, investigations should be performed to evaluate for associated symptoms. In the case of multiple myeloma, the symptoms are classically denoted by the acronym CRAB (hyperCalcaemia, Renal impairment, Anaemia, and Bone lesions) (Fig. 3). Waldenström macroglobulinaemia, a B-cell lymphoproliferative disorder, characterised by the presence of an IgM monoclonal protein, requires assessment of lymphadenopathy and splenomegaly. AL amyloidosis can result in multi-organ infiltration, most commonly affecting the kidneys, liver, heart, gastrointestinal tract and peripheral nerves, and therefore warrants a comprehensive clinical assessment.

\section{Cases revisited}

Case 1 describes a woman with normocytic anaemia and indices suggestive of inflammation (elevated platelet count, C-reactive protein and IgG level). While quantitative immunoglobulin tests were performed, the patient has not yet had appropriate investigations to assess clonality, which would include an SPEP with immunofixation and a serum FLC assay.

Case 2 depicts a patient with symptoms of multiple myeloma, with an IgG kappa monoclonal protein of $10 \mathrm{~g} / \mathrm{L}$ identified on SPEP and immunofixation. A diagnosis of multiple myeloma was confirmed when a bone marrow biopsy demonstrated $16 \%$ clonal plasma cells.

Case 3 demonstrates a patient with a high pretest probability of multiple myeloma due to the presence of multiple CRAB symptoms; yet, the SPEP and immunofixation were negative. This highlights the insensitivity of the SPEP and immunofixation in isolation to reliably detect the minority of patients who have light-chain disease. Further testing with a serum FLC assay is required to complete the monoclonal investigation. A practical approach to the evaluation of monoclonal proteins is outlined in Table 2 . 


\section{Table 2. A practical approach to monoclonal protein investigation}

Does my patient have a clinical presentation warranting a monoclonal protein investigation?

Have I ordered the appropriate tests to assess clonality?

Have I looked for both monoclonal immunoglobulins and FLCs?

If positive, have I looked for consequences of disease?
- Hypercalcaemia with normal or low PTH

- Renal insufficiency with bland urinary sediment, unexplained proteinuria or Bence Jones proteinuria

- Unexplained anaemia

- Osteolytic bone lesions, spontaneous fractures, osteoporosis

- Immune

- Hypergammaglobulinaemia, immunoglobulin deficiency

- Suspicion for AL amyloidosis or Waldenström macroglobulinaemia

- Immunoglobulins

- SPEP: how much?

- Immunofixation: what type?

- Light chains: serum FLC assay

- Elevations in total protein or quantitative immunoglobulins do not confirm clonality (see 'Polyclonal gammopathy' in Fig. 3)

- Hypercalcaemia

- Renal impairment

- Anaemia

- Bone disease

- Lymphadenopathy (IgM subtype)

- Splenomegaly (IgM subtype)

- Multi-organ infiltration (AL amyloidosis)

PTH = parathyroid hormone; $\mathrm{AL}$ amyloidosis = amyloid light-chain amyloidosis; SPEP = serum protein electrophoresis; FLC $=$ free light chain.

\section{Conclusions}

In summary, monoclonal protein investigations are indicated in the work-up of multiple myeloma and other plasma cell disorders. Testing requires confirmation of clonality using an SPEP with immunofixation and serum FLC assay. UPEP is no longer required as a screening test for monoclonal proteins, with the exception of $\mathrm{AL}$ amyloidosis. Abnormal results should prompt a clinical evaluation for signs and symptoms of disease to distinguish the premalignant monoclonal gammopathy of undetermined significance from established haematological malignancy.

\section{Declaration. None.}

Acknowledgements. None.

Author contributions. All authors were involved in the conceptual design of this review. BLH drafted the manuscript, which was reviewed and revised by $\mathrm{ER}, \mathrm{RZ}$ and $\mathrm{MS}$

Funding. BLH receives operating funding from the Canadian Institutes of Health Research (CIHR), and salary funding from the Clinician Investigator Program at the University of Manitoba, Winnipeg, Canada. RZ receives an operating salary and operating funding from the CIHR and the Lyonel G Israels Professorship in Hematology at the Max Rady College of Medicine, Winnipeg, Canada.

Conflicts of interest. None.

1. Steensma DP, Cuker A, Kempton CL, Nowakowski GS, eds. American Society of Hematology SelfAssessment Program. 6th ed. Washington, DC: American Society of Hematology, 2016.

2. Katzmann JA, Kyle RA, Benson J, et al. Screening panels for detection of monoclonal gammopathies.

Clin Chem 2009;55(8):1517-1522. https://doi.org/10.1373/clinchem.2009.126664

3. Bradwell AR, Carr-Smith HD, Mead GP, et al. Highly sensitive, automated immunoassay for

immunoglobulin free light chains in serum and urine. Clin Chem 2001;47(4):673-680.
4. Jenner E. Serum free light chains in clinical laboratory diagnostics. Clin Chim Acta 2014;427:15-20. https://doi.org/10.1016/j.cca.2013.08.018

5. Kyle RA, Gertz MA, Witzig TE, et al. Review of 1027 patients with newly diagnosed multiple myeloma. Mayo Clin Proc 2003;78(1):21-33. https://doi.org/10.4065/78.1.21

6. Piehler AP, Gulbrandsen N, Kierulf P, Urdal P. Quantitation of serum free light chains in combination with protein electrophoresis and clinical information for diagnosing multiple myeloma in a general hospital population. Clin Chem 2008;54(11):1823-1830. https://doi.org/10.1373/ clinchem.2008.106153

7. Vermeersch P, van Hoovels L, Delforge M, Marien G, Bossuyt X. Diagnostic performance of serum free light chain measurement in patients suspected of a monoclonal B-cell disorder. Br J Haematol 2008;143(4):496-502. https://doi.org/10.1111/j.1365-2141.2008.07369.x

8. Abadie JM, van Hoeven KH, Wells JM. Are renal reference intervals required when screening for Abadie JM, van Hoeven $\mathrm{KH}$, Wells $\mathrm{JM}$. Are renal reference intervals required when screening for
plasma cell disorders with serum free light chains and serum protein electrophoresis? Am J Clin Pathol 2009:131(2):166-171. https///doi.rg/10.1309/AJCPR2M4EUYNHLGM

9. Hutchison CA, Harding S, Hewins P, et al. Quantitative assessment of serum and urinary polyclonal Hutchison CA, Harding S, Hewins P, et al. Quantitative assessment of serum and urinary polyclonal
free light chains in patients with chronic kidney disease. Clin J Am Soc Nephrol 2008;3(6):1684-1690. free light chains in patients with chron

10. Katzmann JA, Dispenzieri A, Kyle RA, et al. Elimination of the need for urine studies in the screening algorithm for monoclonal gammopathies by using serum immunofixation and free light chain assays. Mayo Clin Proc 2006;81(12):1575-1578. https://doi.org/10.4065/81.12.1575

11. McTaggart MP, Lindsay J, Kearney EM. Replacing urine protein electrophoresis with serum free light chain analysis as a first-line test for detecting plasma cell disorders offers increased diagnostic accuracy and potential health benefit to patients. Am J Clin Pathol 2013;140(6):890-897. https://doi. org/10.1309/ajcp25ihylewcahj

12. Dimopoulos M, Kyle R, Fermand JP, et al. Consensus recommendations for standard investigative workup: Report of the International Myeloma Workshop Consensus Panel 3. Blood 2011;117(18):47014705. https://doi.org/10.1182/blood-2010-10-299529

13. Dispenzieri A, Kyle R, Merlini G, et al. International Myeloma Working Group guidelines for serumfree light chain analysis in multiple myeloma and related disorders. Leukemia 2009;23(2):215-224. https://doi.org/10.1038/leu.2008.307

14. Kyle RA, Therneau TM, Rajkumar SV, et al. Prevalence of monoclonal gammopathy of undetermined significance. N Engl J Med 2006;354(13):1362-1369. https://doi.org/10.1056/NEJMoa054494

15. Landgren O, Katzmann JA, Hsing AW, et al. Prevalence of monoclonal gammopathy of undetermined significance among men in Ghana. Mayo Clin Proc 2007;82(12):1468-1473. https://doi.org/10.1016/ significance among men

16. Mergenthaler U, Heymanns J, Koppler H, et al. Evaluation of psychosocial distress in patients treated in a community-based oncology group practice in Germany. Ann Oncol 2011;22(4):931-938. https:// doi.org/10.1093/annonc/mdq455

17. Go RS, Swanson KM, Sangaralingham LR, Habermann EB, Shah ND. Clinical prevalence (diagnosed cases) of monoclonal gammopathy of undetermined significance in the US: Estimating the burden on health care. Leukemia 2016;30(6):1443-1446. https://doi.org/10.1038/leu.2015.33

18. Rajkumar SV, Dimopoulos MA, Palumbo A, et al. International Myeloma Working Group updated criteria for the diagnosis of multiple myeloma. Lancet Oncol 2014;15(12):e538-e548. https://doi. org/10.1016/s1470-2045(14)70442-5

Accepted 29 July 2019 